\title{
Glacier Fluctuations in the Northern Patagonian Andes (44. S) Imply Wind-Modulated Interhemispheric in Phase Paleoclimates During Termination 1
}

\section{Rodrigo L Soteres ( $\square$ rlsoteres@uc.cl ) \\ Pontificia Universidad Católica de Chile \\ Esteban A Sagredo \\ Pontificia Universidad Católica de Chile \\ Michael R Kaplan \\ Lamont-Doherty Earth Observatory \\ Mateo A Martini \\ Universidad Nacional de Córdoba}

Patricio I Moreno

Universidad de Chile

Scott A Reynhout

Universidad de Chile

Roseanne Schwartz

Lamont-Doherty Earth Observatory

Joerg M Schaefer

Columbia University

\section{Research Article}

Keywords:

Posted Date: March 7th, 2022

DOI: https://doi.org/10.21203/rs.3.rs-1389274/v1

License: @ (i) This work is licensed under a Creative Commons Attribution 4.0 International License. Read Full License 


\section{Abstract}

The Last Glacial Termination (T1) featured major changes in global circulation systems that led to a shift from glacial to interglacial climate. While polar ice cores attest to an antiphased thermal pattern at millennial timescales, recent well-dated moraine records from both hemispheres suggest in-phase fluctuations in glaciers through $\mathrm{T} 1$, which is inconsistent with the bipolar see-saw paradigm. Here, we present a glacier chronology based on 30 new 10Be surface exposure ages from well-preserved moraines in the Lago Palena/General Vintter basin in northern Patagonia $\left(\sim 44^{\circ} \mathrm{S}\right)$. We find that local glacier lobe underwent profound retreat after $19.7 \pm 0.7 \mathrm{ka}$. This recessional trend led to the individualization of the Cerro Riñón glacier by $~ 16.3$ ka, which readvanced at 15.9 \pm 0.7 ka during Heinrich Stadial 1; during the Antarctic Cold Reversal with successive maxima at $13.5 \pm 0.6,13.1 \pm 0.5$, and $13.1 \pm 0.5 \mathrm{ka}$; and a minor culmination at $12.5 \pm 0.4$ ka during Younger Dryas time. We conclude that fluctuations of Patagonian glaciers during $\mathrm{T} 1$ were controlled primarily by climate anomalies brought by shifts on the Southern Westerly Winds (SWW) locus. We posit that the global covariation of mountain glaciers during T1 was linked to variations in atmospheric $\mathrm{CO} 2$ promoted by the interplay of the SWW-Southern Ocean system at millennial timescales.

\section{Full Text}

The Last Glacial Termination ( $\mathrm{T} 1 ; \sim 17.8-11.7 \mathrm{ka}$ ) represents the largest, most abrupt climate change of the last glacial-interglacial cycle [1]. T1 featured the collapse of continental-scale ice sheets, a persistent rise in sea level and the concentration of atmospheric greenhouse gases, along with a millennial-scale sequence of climate changes that culminated with the onset of the current interglacial. Ice core data reveal a step like pattern of increasing atmospheric temperatures featuring a synchronous but antiphased trend at millennial timescale between the polar hemispheres [2, 3]. Recently developed precise mountain glacier chronologies in the mid-to-high latitudes of both hemispheres [4,5,6,7; see methods], however, are starting to reveal in-phase behavior, pointing to a globally consistent mountain glacier response to climate changes during T1. This pattern challenges the expected antiphased or out-of-phase response predicted by the bipolar seesaw paradigm. If replicated by detailed and precise glacial chronologies, this mismatch could reveal key insights about interhemispheric climate links mediated by some atmospheric component operative during glacial terminations.

Recently, Denton et al. [8] proposed that changes in the SWW are the critical missing link relating insolation, atmospheric greenhouse gas concentrations, atmospheric and ocean circulation, and glacier response at millennial timescale during glacial maxima and terminations. In their interaction with the So, the SWW establish a coupled system that drives global ocean circulation, the atmospheric concentration of greenhouse gases, and high-latitude ocean productivity by enhancing upwelling of $\mathrm{CO}_{2}$-enriched and high-nutrient deep waters $[9,10]$. The efficacy of the SWW-SO coupled system is dependent upon the wind stress imparted by the SWW on the surface of the SO south of the Drake Passage $\left(>55^{\circ} \mathrm{S}\right)$. Hence, deciphering the geographical position and strength of the locus of the SWW are crucial for assessing global climate change during ice age terminations. 
The SWW are the sole source of precipitation to the Pacific sector and Andean divide sectors of northern Patagonia $\left(40^{\circ}-44^{\circ} \mathrm{S}\right)$ [11]. This key aspect allows reconstructing past SWW behavior based on hydrologic balance variations preserved in sensitive stratigraphic records from the Chilean Lake District and the Chiloé archipelago $\left(40-44^{\circ} \mathrm{S}\right)$. When analyzed in conjunction with records from southern Patagonia $\left(50^{\circ}-54^{\circ} \mathrm{S}\right)$, these records permit the identification of latitudinal shifts and intensity variations in the SWW at millennial-scale during the Last Glacial Maximum (LGM; 35 - $18 \mathrm{ka}$ ) and T1 [12, 13]. However, few studies in northern Patagonia have examined in any detail glacier fluctuations following the onset of T1 $[14,15]$, limiting our understanding about the response of middle latitude austral glaciers and paleoclimate patterns and processes at continental, hemispheric, and global scales.

Mountain glaciers are sensitive to and provide a direct physical link to changing atmospheric conditions. For land-terminating glaciers in particular, moraines distal to present ice limits are unambiguous recorders that past climate changed. Thus, the anatomy of glacier fluctuations during $\mathrm{T} 1$ in the southern mid-latitudes not only offers empirical constraints on the interhemispheric synchrony of mountain glacier behavior, but also a means to examine the evolution of the SWW and associated paleoclimates. In this study, we present a detailed glacial geomorphologic map and a highly resolved ${ }^{10} \mathrm{Be}$ geochronology of the Lago Palena/General Vintter (LPGV) basin $\left(\sim 43.9^{\circ} \mathrm{S} ; \sim 71.5^{\circ} \mathrm{W}\right)$ in northern Patagonia, to examine the timing and structure of glacier fluctuations during T1. This basin was covered by an eastward-flowing outlet lobe of the Patagonian Ice Sheet that was fed through several coalescing valleys during the LGM (Fig. 1) [16]. The core of our chronology comes from one of these tributary valleys located $\sim 15 \mathrm{~km}$ from the southern shore of the lake, at the foot of Cerro Riñón ( $1790 \mathrm{~m}$ asl). The Cerro Riñón valley (informal name) is carved into the North Patagonian batholith [17], which was the source of the abundant granitoid boulders found on the local landscape.

\section{Results}

Previous studies delineated multiple moraines alongside the eastern half of the LPGV, which have been tentatively assigned to the $\operatorname{LGM}[15,16,18,19]$. Our geomorphological map allows identification of at least six well-preserved, closely spaced and concentric moraine ridges, the innermost of which we name PV6 (Fig. 1). We obtained four ${ }^{10}$ Be dates from boulders atop PV6, which yielded ages between $20.7 \pm 0.4$ and $18.9 \pm 0.4 \mathrm{ka}$, with a mean of $19.7 \pm 0.7 \mathrm{ka}$ (Fig. 1, Table 1). Upstream from the PV moraines, within the Cerro Riñón tributary valley, we distinguish five well-preserved moraine groups (CR1 to CR5 from the outermost to the innermost). A single ${ }^{10} \mathrm{Be}$ date from a perched erratic boulder resting over polished bedrock outboard of the CR1 moraines, and $\sim 30 \mathrm{~m}$ above the modern lake surface, affords an age of $16.3 \pm 0.4 \mathrm{ka}$. The CR1 moraines lie $~ 300 \mathrm{~m}$ south from the lake shore and comprise a $\sim 500 \mathrm{~m}$ long and $\sim 10 \mathrm{~m}$ high main ridge connected to several minor ridges (Supplementary Fig. $2 \mathrm{~s}$ ). We obtained seven

${ }^{10} \mathrm{Be}$ dates that range from $16.6 \pm 0.4$ to $15.3 \pm 0.4 \mathrm{ka}$, with a mean of $15.9 \pm 0.5 \mathrm{ka}$. Directly inside CR1 we find two ridges that form the CR2 moraines, clearly distinguishable by their larger sizes $(\sim 700 \mathrm{~m}$ long and $\sim 20 \mathrm{~m}$ high) and sharper appearance (Supplementary Fig. $2 \mathrm{~s}$ ). Six ${ }^{10} \mathrm{Be}$ dates from the largest and most continuous ridge yielded ages between $14.0 \pm 0.2$ to $13.1 \pm 0.2 \mathrm{ka}$, with a mean of $13.5 \pm 0.4 \mathrm{ka}$. 
Immediately inboard, separated by a meltwater channel, we find the CR3 moraine that represents the most continuous ( $1000 \mathrm{~m}$ long) and prominent ( $30 \mathrm{~m}$ high) ice-marginal feature of the area. We obtained seven ${ }^{10} \mathrm{Be}$ dates that range in age from $13.5 \pm 0.3$ to $12.9 \pm 0.3 \mathrm{ka}$, with a mean of $13.1 \pm 0.4 \mathrm{ka}$. Approximately $200 \mathrm{~m}$ upstream from CR3, separated by an outwash plain, a group of several discontinuous ridges covered by dense vegetation form the CR4 moraine (Supplementary Fig. 2s). Two samples from the outermost moraine ridge of CR4 provide ages of $13.5 \pm 0.3$ and $12.9 \pm 0.3$, with a mean of $13.1 \pm 0.5 \mathrm{ka}$ (the additional sample LV17-30 (10.6 $\pm 0.2 \mathrm{ka}$ ) was excluded as an outlier [20]) (Fig. 1, Table 1). CR5 comprises the innermost ice-marginal features, located $\sim 500 \mathrm{~m}$ upstream from CR4, and consists of a $\sim 400 \mathrm{~m}$ long group of latero-frontal moraine ridge fragments elevated $\sim 20 \mathrm{~m}$ above the floor of the most extensive outwash plain in this valley. Two ${ }^{10} \mathrm{Be}$ dates collected from the outermost ridge yielded statistically identical ages of $12.5 \pm 0.2 \mathrm{ka}$.

\section{Discussion}

Glacial geologic mapping and thirty new ${ }^{10} \mathrm{Be}$ ages (1 outlier) constitute the basis of a moraine chronology for the LPGV basin that captures in unprecedented detail the sequence of glacier/paleoclimatic events during T1 in northern Patagonia. Our data indicate that the LPGV glacier lobe abandoned the PV6 moraine sometime after $19.7 \pm 0.7 \mathrm{ka}$. Considering the dispersion of the PV6 ages, and the significant number of undated ridges within this moraine belt, we interpret this date as a maximum-limiting age for the onset of major glacier withdrawal. The ice front then retreated more than $40 \%$ of its LGM length, prompting the detachment of the Cerro Riñón glacier shortly after $16.3 \pm 0.4 \mathrm{ka}$. After this event, an advance of this tributary glacier culminated with the deposition of the CR1 moraine at $15.9 \pm 0.5 \mathrm{ka}$. Subsequent advances deposited the statistically indistinguishable but geomorphologically distinct CR2 to CR4 moraines between $13.5 \pm 0.4$ and $13.1 \pm 0.5 \mathrm{ka}$. Cerro Riñón glacier then underwent net recession, only interrupted by a stillstand that constructed CR5 at $12.5 \pm 0.4 \mathrm{ka}$. No ice marginal features are evident up valley, suggesting irreversible glacier retreat to the headwalls after $\sim 12.5 \mathrm{ka}$. The chronology for the Cerro Riñón glacier informs us, for the first time in northern Patagonia, the timing and structure of glacier fluctuations throughout the entirety of T1 within a single basin, and constrains four moraine deposition phases of similar magnitude (i.e., CR1-CR4) that culminated at $~ 15.9$ ka during Heinrich Stadial 1 (HS1: 17.8-14.7 ka) and between 13.5-13.1 ka within the Antarctic Cold Reversal (ACR: 14.7-12.7 ka), followed by an additional advance or stillstand of minor extent (i.e., CR5) at $~ 12.5$ ka coeval with the Younger Dryas (YD: 12.6-11.5 ka).

The Cerro Riñón glacier expanded and achieved its maximum extent during T1 by 15.9 $\pm 0.5 \mathrm{ka}$. This result differs from the majority of moraine-based records from southern South America dated so far, which document an apparent sustained and irreversible glacier recession during HS1. Notable exceptions are moraines of similar age observed along the eastern flank of the southern Patagonian Andes at the ${ }^{10}$ Be dated Cerro Pintado moraine at Río Guanaco ( 50 $\left.{ }^{\circ} \mathrm{S}\right)$ [21] and the ${ }^{14} \mathrm{C}$-constrained Lago Pinto moraine at Última Esperanza $\left(\sim 50^{\circ} \mathrm{S}\right)$ [22]. Subsequent glacier activity in the Cerro Riñón valley represents the northernmost direct evidence for glacier advances during the ACR and gradual retreat 
during the YD in Patagonia, expanding their known geographical footprint from $47.5^{\circ} \mathrm{S}$ to $43.9^{\circ} \mathrm{S}[23,24$, $25,26]$. The recent interpretation of an ACR maximum based on geomorphic analysis and lake sedimentary record of former Rosselot glacier [27], $45 \mathrm{~km}$ directly west of Cerro Riñón, is consistent with our conclusions. The Patagonian findings indicate that ELA depressions at $\sim 15.9$ ka and during the ACR were similar in magnitude and were followed by a net ELA rise during the YD, accounting for modest glacier advances or standstills well within ACR limits. At similar latitude, but $~ 9000 \mathrm{~km}$ west of LPGV, several moraine records in New Zealand reflect synchronous glacier behavior: deep recession from the LGM limits was punctuated by deposition of the Prospect Hill moraines at $\sim 15.9$ ka in the Rakaia valley [28], which was followed by several ACR advances, and then subsequent YD recession was interrupted by minor stillstands in multiple valleys of the Southern Alps [29, 30, 31]. We propose that trans-Pacific coordinated glacier fluctuations at millennial timescales through T1 most likely involves zonally symmetric changes in the SWW and associated climate anomalies $[23,30]$.

We assess the representativity behavior of the Cerro Riñón glacier record with proxy evidence from lake sediment cores obtained in the Pacific sector of northern Patagonia, which afford valuable information for tracking the regional evolution of the SWW through the LGM and T1 [32, 33, 34]. Pollen records from the Chilean Lake District and Isla Grande de Chiloé [35] show a treeline depression of $\sim 1000 \mathrm{~m}$ and presence of Magellanic Moorland communities during the LGM, attesting to cold and hyperhumid conditions brought by a northward shift of the SWW (Fig. 2). This was followed by rapid arboreal expansion, disappearance of Magellanic Moorland driven by deglacial warming and a southward shift of the SWW starting at $\sim 17.8 \mathrm{ka}$. The interval between $~ 17.8-16.4$ ka features a low lake-level stand, with peak abundance of the littoral macrophyte Isoetes (Fig. 2), signaling low SWW influence during the initial portion of T1. Discrete increases in precipitation occurred at $\sim 16.4 \mathrm{ka}$ and $\sim 14.7 \mathrm{ka}$, as indicated by conspicuous increases in cold-tolerant hygrophilous conifers (Fitzroya/Pilgerodendron and Podocarpus nubigena, respectively). These changes suggest successive increments in SWW influence in northern Patagonia. The earliest of these increases lasted until $\sim 15.9 \mathrm{ka}$, as the deglacial warming trend resumed and crossed a critical threshold that favored the diversification and densification of other thermophilous rainforest trees and vines at the expense of Fitzroya/Pilgerodendron. The most recent increase in conifers (Podocarpus nubigena) during T1 took place between 14.7-12.6 ka, and was followed by enhanced fire activity, a lake-level decline, and decline in conifers after $~ 12.6 \mathrm{ka}$, which suggest a decline in precipitation related to a southward shift of the SWW. Wind-driven hydroclimate changes toward cold/wet conditions closely track glacier advances in the LPGV area. We therefore conclude that our record shows a coherent cryospheric response to significant SWW-modulated climate fluctuations during T1. Additionally, we note that the reservoir-age corrected paleoclimate records from marine core ODP1233 [36], collected offshore from northwestern Patagonia (Fig. 3), show a pattern consistent with our terrestrial-based chronology of climate change through $\mathrm{T} 1$.

Widespread glacier withdrawal in Patagonia [37] was contemporaneous with distinct atm $\mathrm{CO}_{2}$ increments recorded at the beginning and end of $\mathrm{T} 1$, between $~ 18.1-16.3 \mathrm{ka}$ and $\sim 13-11.7 \mathrm{ka}$ in the WAIS ice core [38], enhanced ocean ventilation inferred from a rise in opal flux recorded in the SO [9], and reduced $\delta^{13} \mathrm{C}$ 
composition of atmCO 2 preserved in the EDC and TALDICE ice cores from Antarctica [39] (Fig. 3). Glacier advances or stillstands that stalled deep recession in northern Patagonia coincided with centennial-scale halts in the rising atmCO $\mathrm{CO}_{2}$ trend followed by atmCO ${ }_{2}$ plateaus between $~ 16.3-14.8 \mathrm{ka}$ and $\sim 14.8-13.0$ ka [38], concomitant with decreased deep SO water ventilation [9] and minimum $\delta^{13} \mathrm{C}$ composition of atmCO $\mathrm{Crom}_{2}$ Antarctic ice cores [39] (Fig. 3).

Our collation of mid- and high-latitude paleoclimate data from the Southern Hemisphere suggests that variations in the strength/position of the SWW are the common denominator for hydroclimate changes and glacier mass balance variations in the temperate regions of South America and New Zealand, along with upwelling and ventilation of deep waters in the SO through T1. Overall, we note that negative mass balance driving glaciers recession from their LGM terminus in the LPGV basin was contemporaneous with negative anomalies in SWW influence in northwestern Patagonia [35] and sustained increase in atm $\mathrm{CO}_{2}$ [38] coinciding with invigorated SO upwelling [9]. Collectively, these data indicate a poleward shift of the SWW early during T1 [9]. Subsequently, positive glacier mass balance episodes culminating at $\sim 15.9$ were concomitant with positive anomalies in SWW at $\sim 44^{\circ} \mathrm{S}$ [35], a pause in the rising trend of atmCO $\mathrm{C}_{2}$ rapidly starting at $16.3 \mathrm{ka}$ [38], and subdued increase in SO upwelling [9]. We interpret these correspondences as a concomitant widening of the SWW belt during the HS1. This was followed by enhanced positive glacier mass balance accounting for multiple readvances between $\sim 13.5-13.1 \mathrm{ka}$ coeval with positive anomalies of the SWW in northwestern Patagonia [35], and a stall in the rising of atm $\mathrm{CO}_{2}$ trend [38] accompanied by attenuated degassing of the SO [9]. We interpret these data as increased SWW influence at $\sim 44^{\circ} \mathrm{S}$ and diminished influence south of $\sim 55^{\circ} \mathrm{S}$, over the SO, implying a northward shift of the SWW belt. Finally, recurrent negative glacier mass balance prior to $\sim 12.5$ ka was coeval with negative anomalies in SWW influence in northwestern Patagonia [35], resumption of the atmCO $\mathrm{C}_{2}$ rising trend [38], and enhanced SO upwelling [9]. This correspondence suggests to us diminished SWW influence at $\sim 44^{\circ} \mathrm{S}$ and stronger SWW influence south of $\sim 51^{\circ} \mathrm{S}$, implying a southward shift of the SWW belt during the YD.

The Cerro Riñón glacier chronology also shares similarities with mountain glacier chronologies from the mid and high northern latitudes [37] (Supplementary 3s). Those studies show glacier withdrawal from their LGM limits shortly after the onset of T1 at $~ 18.5 \mathrm{ka}[39,40]$, readvances between $\sim 17-16 \mathrm{ka}$ in multiple valleys of the European Alps [40, 41, 42] and between 16.5-15.7 ka in western North America [43], broadly contemporaneous with the deposition of the CR1 moraine during HS1. A growing body of evidence indicates that glaciers readvanced between $~ 14.5-13.5 \mathrm{ka}$ in the Norwegian Arctic [5], between 14.3-12.8 ka in east Greenland [44], and between 14.5-12.8 ka in western North America [45], coeval with the formation of the CR2-CR4 moraines during the ACR. Subsequent moraine formation events between 12.8-12.3 ka in east Greenland [46], southern Alaska [6], and Scotland [7] occurred during the early YD, and several sites across the European Alps during the late YD [47, 48, 49, 50, 51]. These advances or standstills are indistinguishable in age, considering dating uncertainties, with the CR5 moraine, just before widespread and irreversible recession to the valley headwalls. We acknowledge that significant glacial activity during T1 occurred within the YD and few dates overlapping with the ACR have 
been reported in the majority of northern hemisphere sites [37]. A large number of these glacier advances, however, culminated either early or late within the interval (Supplementary), indicating that glaciers were receding through much of the YD.

The pervasive interhemispheric synchrony in mountain glaciation during T1 lies in direct contrast to the largely antiphased polar ice core records (Fig. 3). Studies have attributed the severity of cooling in Greenland ice cores throughout HS1 and YD time to a seasonality switch related to episodes of extended sea ice cover in the North Atlantic region, skewing their isotopic records toward a predominantly winter temperature signal $[52,53]$. Mountain glacier fluctuations, in contrast, respond primarily to summer temperatures which remained comparatively warm during key episodes of $\mathrm{T} 1$ as reflected by modelling experiments complemented with multiproxy records from Europe [54].

Our results and analysis show that the timing and structure of glacier fluctuations in the LPGV basin were coeval with climate events recorded in both the northern (i.e., HS1 and YD) and southern (i.e., ACR) hemispheres. From our interhemispheric comparison we interpret synchrony of mountain glaciers driven by a global climate signal during $\mathrm{T} 1$, challenging the expected antiphase behavior predicted from the bipolar seesaw paradigm. This finding favors an atmospheric mechanism for generating and globally propagating millennial-scale climate variability during $\mathrm{T} 1$. We conclude that high-to-middle latitude mountain glaciers fluctuated in phase during T1 partly in response to summer warming due to atmCO concentrations brought by changes in the SWW-SO coupled system [4, 8].

\section{Methods}

Geomorphological mapping. Detailed geomorphological mapping of the moraine limits in Lago Palena/General Vintter basin was conducted based on satellite imagery (Sentinel 2), aerial photographs (GEOTEC 1:50,000) and digital elevation models (ALOS Palsar). The preliminary map was checked during two field campaigns (March, September 2017 and January 2020).

Rock samples collection. We collected 26 boulder samples for ${ }^{10} \mathrm{Be}$ surface exposure dating from the Cerro Riñón moraines (CR complexes), in addition to one sample from a perched boulder (LV-17-42) located immediately outboard of the outermost moraine limit, and 4 boulder samples from the innermost moraine ridge along the eastern shore of Lago Palena/General Vintter (i.e., PV6). We aimed for large boulders to avoid potential effects of post-depositional movements or posterior exhumation. Samples were taken from the upper $\sim 4 \mathrm{~cm}$ of the boulder surfaces using a drill and explosive charges, avoiding areas exhibiting clear signs of erosion, such as spalling or flaking. Elevation and geographic coordinates of each rock sample were recorded with a handheld GPS unit (WGS84). We measured topographic shielding using a handheld compass and a clinometer. Moraine ages are interpreted as representing the culmination of moraine construction, and, thus, cold episodes, whereas the perched-boulder age provides a minimum age for ice retreat from the sampling site. 
Quartz separation and ${ }^{10} \mathrm{Be}$ isolation. Initial crushing and sieving of the rock samples was carried out at the Pontificia Universidad Católica de Chile and subsequent quartz and beryllium extraction at the Cosmogenic Nuclide Laboratory at Lamont-Doherty Earth Observatory following the protocol outlined in $[55,56] .{ }^{10} \mathrm{Be} /{ }^{9} \mathrm{Be}$ ratios were measured at Lawrence Livermore National Laboratory Center for Accelerator Mass Spectrometry. Ratios were measured relative to the standard 07KNSTD with a ${ }^{10} \mathrm{Be} /{ }^{9} \mathrm{Be}$ ratio of $2.85 \times 10^{-12}$ ([57]; ${ }^{10} \mathrm{Be}$ half-life $=1.36 \mathrm{Myr}$.). Analytical raw data are available in the supplementary material. Given relatively recent improvements described in $[55,56]$, the average analytical uncertainty is $\sim 2 \%$, with almost half the analyses between $1.7 \%$ and $2.0 \%$.

10 Be surface exposure ages. ${ }^{10} \mathrm{Be}$ ages were calculated based on methods incorporated in the CRONUSEarth online exposure age calculator (v.3) [58], considering the time-dependent Lal/Stone [59, 60] scaling schemes and the regional Patagonian production rate $\left(\sim 50^{\circ} \mathrm{S}\right)[56]$, assuming zero erosion and a rock density of $2.65 \mathrm{~g} / \mathrm{cm}^{3}$. We show in Table 1 that ${ }^{10} \mathrm{Be}$ ages are statistically identical (i.e., accuracy) using other scaling methods. In the text, we report individual ${ }^{10} \mathrm{Be}$ ages with $1 \sigma$ analytical uncertainty and the standard error of the mean (SEM). For comparison with other proxy records, mean moraine ages include the propagation of the analytical uncertainty and that of the local production rate (3\%) [56]. Similarly, for glacier ${ }^{10} \mathrm{Be}$ chronologies in New Zealand, we used a local production rate $\left(\sim 43.6^{\circ} \mathrm{S}\right)$ and the associated uncertainties include a $2 \%$ error [61].

\section{Declarations}

\section{Acknowledgements}

This research was supported by National Ph.D. Fellowship CONICYT \#21161417, FONDECYT \#1160488 and ANID Millennium Science Initiative/Millennium Nucleus Paleoclimate NCN17_079. We also thank P. Ugalde, C. Peltier and E. Flores for field logistic support. We additionally thank J. Hanley and J. Frisch for laboratory support.

\section{Author contributions}

R.L.S. and E.A.S. designed the study with conceptual contributions by all co-authors. R.L.S. performed geomorphological mapping and lab analysis. Fieldwork was conducted by R.L.S., E.A.S. and M.A.M. P.I.M. helped with palynological data curation and interpretation. S.A.R. discovered the study area. M.R.K. R.S. and J.M.S. participated on initial conceptualization and lab analysis. All the co-authors contributed to the formal analysis and interpretation of the results. R.L.S. wrote the initial draft of the paper and all the coauthors reviewed it.

\section{Competing interests}

The authors declare no competing interests. 
All data generated during the current study are included in this published article as a supplementary file.

\section{References}

1. Denton, G. H. et al. The Last Glacial Termination. Science. 328, 1652-1656 (2010).

2. WAIS, D. M. Onset of deglacial warming in West Antarctica driven by local orbital forcing. Nature. 500(7463), 440-444 (2013).

3. Rasmussen, S. O. et al. A new Greenland ice core chronology for the last glacial termination. J. Geophys. Res. Atm. 111(6), 1-16 (2006).

4. Shakun, J. D. et al. Regional and global forcing of glacier retreat during the last deglaciation. Nature Comm. 6, 8059 (2015).

5. Wittmeier, H. E. et al. Late Glacial mountain glacier culmination in Artic Norway prior to Younger Dryas. Quat. Sci. Rev. 245, 106461 (2020).

6. Young, N. E., Briner, J. P., Schaefer, J.M., Zimmerman, S., \& Finkel, R. C. Early Younger Dryas glacier culmination in southern Alaska: Implications for North Atlantic climate change during the last deglaciation. Geology 47, 550-554 (2019).

7. Bromley, G., Puntnam, A., Borns, H. Jr., Lowell, T., Sandford, T., \& Barrel, D. Interstadial rise and Younger Dryas demise of Scotland's last ice field. Paleocen. \& Paleoclim. 33, 412-429 (2018).

8. Denton, G. H., et al. The Zealandia Switch: Ice age climate shifts viewed from Southern Hemipshere moraines. Quat. Sci. Rev. 255, 106771 (2021).

9. Anderson, R. F. et al. Wind-Driven upwelling in the Southern Ocean and the Deglacial Rise in Atmospheric CO2. Science, 323, 1443-1448 (2009).

10. Toggweiler, J., Russell, J., \& Carson, S. Midlatitude westerlies, atmospheric CO2, and climate change during the ice ages. Paleoceanography. 21, PA2005 (2006).

11. Garreaud, R., Lopez, P., Minvielle, M., \& Rojas, M. Large-scale control on the Patagonian climate. J. of Climate. 26(1), 215-230 (2013).

12. Moreno, P. I. et al. Radiocarbon chronology of the last glacial maximum and its termination in northwestern Patagonia. Quat. Sci. Rev. 122, 233-249 (2015).

13. Moreno, P. I., Videla, J., Valero-Garcés, B., Alloway, B. V., \& Heusser, L. E. A continuous record of vegetation, fire-regime and climatic changes in northwestern Patagonia spanning the last 25,000 years. Quat. Sci. Rev. 198, 15-36 (2018).

14. Denton, G. H., et al. Geomorphology, Stratigraphy, and radiocarbon chronology of Llanquihue drift in the area of the southern Lake District, Seno Reloncaví, and Isla Grande de Chiloé, Chile. Geog. Anna., 81A(2), 167-229 (1999).

15. Leger, T. P. M., Hein, A. S., Bingham, R. G., Rodés, A., Fabel, D., \& Smedley, R. K. Geomorphology and ${ }^{10} \mathrm{Be}$ chronology of the Last Glacial Maximum and deglaciation in northeastern Patagonia, $43^{\circ} \mathrm{S}$ 71W. Quat. Sci. Rev. 272, 107194 (2021). 
16. Caldenius, C. C. Las glaciaciones cuaternarias en la Patagonia y Tierra del Fuego. Geogr. Ann. A. 14, 1-164 (1932).

17. Castro, A., Rodriguez, C., Fernández, C., Aragón, E., Pereira, M. F., and Molina, J. F. Secular variations of magma source compositions in the North Patagonian Batholith from the Jurassic to Tertiary: Was Mélange melting involved?. Geosphere, 17(3), 766-788 (2021).

18. Leger, T. P. M. et al. The glacial geomorphology of the Río Corcovado, Río Huemul and Lago Palena/General Vintter valleys, northeastern Patagonia $\left(43^{\circ} \mathrm{S}, 71^{\circ} \mathrm{W}\right)$. J. of Maps. $16(2), 651-668$ (2020).

19. Davies, B. J. et al. The evolution of the Patagonian Ice Sheet from $35 \mathrm{ka}$ to the present day (PATICE). Earth Sci. Revs. 204, 103152 (2020).

20. Grubbs, F. E. Procedures for detecting outlying observations in samples. Technometrics. 11(1), 1e21 (1969).

21. Murray, D. S. et al. Northern Hemisphere forcing of the last deglaciation in southern Patagonia. Geology. 40(7), 631-634 (2012).

22. Sagredo, E. A. et al. Fluctuations of the Última Esperanza ice lobe $\left(52^{\circ} \mathrm{S}\right)$, Chilean Patagonia, during the last glacial maximum and termination 1. Geomorphology. 125, 92-108 (2011).

23. Sagredo, E. A. et al. Trans-pacific glacial response to the Antarctic Cold Reversal in the southern midlatitudes. Quat. Sci. Rev. 188, 160-166 (2018).

24. Mendelová, M., Hein, A. S., Rodés, Á., Smedley, R. K., \& Xu, S. Glacier expansion in central Patagonia during the Antarctic Cold Reversal followed by retreat and stabilisation during the Younger Dryas. Quat. Sci. Rev. 227, 106047 (2020).

25. Strelin, J. A., Denton, G. H., Vandergoes, M. J., Ninnemann, U. S., \& Putnam, A. E. Radiocarbon chronology of the late-glacial Puerto Bandera moraines, Southern Patagonian Icefield, Argentina. Quat. Sci. Rev. 30(19-20), 2551-2569 (2011).

26. García, J. L. et al. Glacier expansion in Southern Patagonia throughout the antarctic cold reversal. Geology, 40(9), 859-862 (2012).

27. Moreno, P.I. et al. Vegetation history since the onset of ice-free conditions in the Lago Rosselot sector of Chiloé continental, northwestern Patagonia. Quat. Sci. Rev., 260, 106924.

28. Putnam, A. E. et al. Warming and glacier recession in the Rakaia valley, Southern Alps of New Zealand, during Heinrich Stadial 1. Earth Planet. Sci. Lett. 382, 98-110 (2013).

29. Koffman, T. N. B. et al. A beryllium-10 chronology of late-glacial moraines in the upper Rakaia valley, Southern Alps, New Zealand supports Southern-Hemisphere warming during the Younger Dryas. Quat. Sci. Rev. 170, 14-25 (2017).

30. Putnam, A. E. et al. Glacier advance in southern middle-latitudes during the Antarctic Cold Reversal. Nature Geoscience. 3(10), 700-704 (2010).

31. Kaplan, M. R. et al. Glacier retreat in New Zealand during the Younger Dryas stadial. Nature. 467(7312), 194-197 (2010). 
32. Villagrán, C. Expansion of Magellanic Moorland during the Late Pleistocene: Palynological evidence from Northern Isla de Chiloé, Chile. Quat. Res. 30(3), 304-314 (1988)

33. Moreno, P. I. Vegetation and climate near Lago Llanquihue in the Chilean Lake District between 20,200 and 9,500 14C year BP. Jour. Of Quat. Sci. 12(6), 485-500 (1998).

34. Heusser, C. J., Heusser, L. E., \& Lowell, T. V. Paleoecology of the southern Chilean Lake District-Isla Grande de Chiloé during middle-late Llanquihue glaciation and deglaciation. Geog. Ann. A. 81A(2), 231-284 (1999).

35. Pesce, O. H., \& Moreno, P. I. Vegetation, fire and climate change in central-east Isla Grande de Chiloé $\left(43^{\circ} \mathrm{S}\right)$ since the Last Glacial Maximum, northwestern Patagonia. Quat. Sci. Rev. 90, 143-157 (2014).

36. Lamy, F. et al. Modulation of the bipolar seesaw in the Southeast Pacific during Termination I. Earth Planet. Sci. Lett. 259, 400-413 (2007).

37. Palacios, D. et al. The deglaciation of the Americas during the Last Glacial Termination. Earth Sci. Rev. 203, 103113 (2020).

38. Marcott, S. A. et al. Centennial-scale changes in the global carbon cycle during the last deglaciation. Nature. 514(7524), 616-619 (2014).

39. Schmitt, J. et al. Carbon isotope constraints on the deglacial $\mathrm{CO}_{2}$ rise from ice cores. Science, 336, 711-714 (2012).

40. Wirsig, C., Zasadni, J., Christl, M., Akçar, N., \& Ivy-Ochs, S. Dating the onset of LGM ice surface lowering in the High Alps. Quat. Sci. Rev. 143, 37-50 (2016).

41. Ivy-Ochs, S. Glacier variations in the European Alps at the end of the last glaciation. Cuad. Inv. Geog. 41, 295-315 (2015).

42. Ivy-Ochs, S., Kerschnet, H., Kubik, P. W., Schluchter, C. Glacier response in the European Alps to Heinrich Stadial 1 cooling: the Gschnitz stadial. Jour. Of Quat. Sci. 21(2), 115-130 (2006).

43. Laabs, B. J. C., Licciardi, J. M., Leonard, E. M., Munroe, J. S., \& Marchetti, D. W. Updated cosmogenic chronologies of Pleistocene mountain glaciation in the western United States and Associated paleoclimate inferences. Quat. Sci. Rev. 242, 106427 (2020).

44. Kelly, M. A. et al. A ${ }^{10} \mathrm{Be}$ chronology of lateglacial and Holocene mountain glaciation in the Scoresby Sund regions, east Greenland: implications for seasonality during lateglacial time. Quat. Sci. Rev. 27, 2273-2282 (2008).

45. Marcott, S. A. et al. ${ }^{10} \mathrm{Be}$ constraints on latest Pleistocene and Holocene cirque glaciation across the western United States. Npj Clim. \& Atm. Sci. 2, 5 (2019).

46. Levy, L. B., Kelly, M. A., Lowell, T. V., Hall, B. L., Howley, J. A., \& Smith, C. A. Coeval fluctuations of the Greenland ice sheet and a local glacier, central East Greenland, during late glacial and early Holocene time. Geophys. Res. Lett. 43, 1623-631 (2016).

47. Protin, M., et al. Millennial-scale deglaciation across the European Alps at the transition between the Younger Dryas and the Early Holocene - Evidence from a new cosmogenic nuclide chronology. 
Boreas 50(3), 671-685 (2021).

48. Protin, M. et al. Climatic reconstruction of the Younger Dryas/Early Holocene transition and the Little Ice Age based on paleo-extents of Argentière glacier (French Alps). Quat. Sci. Rev. 221, 105863 (2019).

49. Hofmann, F. M. Glacial history of the upper Drac Blanc catchment (Écrins massif, French Alps). E \& G Quat. Sci. J. 63, 37-40 (2018).

50. Schindelwig, l., Akçar, N., Kubik, P. W., \& Schluchter, C. Lateglacial and early Holocene dynamics of adjacent valley glaciers in the Western Swiss Alps. J. of Quat. Sci. 27(1), 114-124 (2012).

51. Schimmelpfennig, I., Schaefer, J. M., Akçar, N., Ivy-Ochs, S., Finkel, R. C., \& Schluchter, C. Holocene glacier culminations in the Westerns Alps and their hemispheric relevance. Geology 40(10), 891-894 (2012).

52. Denton G. H., Alley, R. A., Comer, G. C., \& Broecker, W. S. The role of seasonality in abrupt climate change. Quat. Sci. Rev. 24, 1159-1182 (2005).

53. Buizert, C. et al. Greenland-wide seasonal temperatures during the last deglaciation. Geophys. Res. Lett. 45, 1905-1914 (2018).

54. Schenk, F. et al. Warms summers during the Younger Dryas cold reversal. Nat. Commun. 9, 1634 (2018).

55. Schaefer, J. M. et al. High-frequency Holocene glacier fluctuations in New Zealand differ from the northern signature. Science. 324(5927), 622-625 (2009).

56. Kaplan,M. R. et al. In-situ cosmogenic ${ }^{10} \mathrm{Be}$ production rate at Lago Argentino, Patagonia: Implications for late-glacial climate chronology. Earth Planet. Sci. Lett. 309(1-2), 21-32 (2011).

57. Nishiizumi, K. et al. Absolute calibration of ${ }^{10} \mathrm{Be}$ AMS standars. Nuc. Inst. Meth. Phys. Res. B. 258, 403-413 (2007).

58. Balco, G., Stone, J., Lifton, N., \& Dunai, T. A complete and easily accessible means of calculating surface exposure ages or erosion rates from 10 Be and $26 \mathrm{Al}$ measurements. Quat. Geochronology, 3(3), 174-195 (2008).

59. Lal, D. Cosmic ray labeling of erosion surfaces: in situ nuclide production rates and erosion models. Earth Planet. Sci. Lett. 104(2-4), 424-439 (1991).

60. Stone, J. O. Air pressure and cosmogenic isotope production. J. Geophys. Res. 105(1), 753-759 (2000).

61. Putnam, A. E. et al. In situ cosmogenic ${ }^{10}$ Be production-rate calibration from the Southern Alps, New Zealand. Quat. Geochronology. 5(4), 392-409 (2010).

62. Lifton, N., Sato, T., \& Dunai, T. Scaling in situ cosmogenic nuclide production rates using analytical approximations to atmospheric cosmic-ray fluxes. Earth Planet Sci. Lett. 386, 149-160 (2014).

\section{Tables}


Table $1 .{ }^{10} \mathrm{Be}$ ages from the Lago Palena/Vintter area calculated using the the non-time-dependent Lal/Stone scaling scheme (St; $[56,57])$ time-dependent Lal/Stone scaling (Lm; $[56,57]$ and Lifton et al scaling (LSDn; [59]). Mean moraine ages are shown in bold with 1 outlier excluded $\left(^{*}\right)$, and are accompanied by the uncertainty ( 1 standard deviation [б]/Standard Error of the Mean [SEM]) considering the propagated error (3\%) of the production rate [53] for both. 


\begin{tabular}{|c|c|c|c|c|}
\hline & Id Sample & Age; St (ka) & Age; Lm (ka) & Age; LSDn (ka) \\
\hline \multirow[t]{5}{*}{ PV6 } & LVM17-19 & $19210 \pm 400$ & $18860 \pm 390$ & $19050 \pm 400$ \\
\hline & LVM17-20 & $21150 \pm 400$ & $20660 \pm 390$ & $20790 \pm 390$ \\
\hline & LVM17-21 & $19760 \pm 570$ & $19370 \pm 560$ & $19530 \pm 560$ \\
\hline & LVM17-23 & $20280 \pm 580$ & $19860 \pm 570$ & $20000 \pm 570$ \\
\hline & Mean $\pm \sigma /$ SEM & $20100 \pm 1030 / 730$ & $19690 \pm 970 / 700$ & $19840 \pm 950 / 700$ \\
\hline \multirow[t]{8}{*}{ CR1 } & LV17-15 & $16620 \pm 310$ & $16440 \pm 310$ & $16640 \pm 310$ \\
\hline & LV17-17 & $15640 \pm 330$ & $15510 \pm 330$ & $15690 \pm 330$ \\
\hline & LV17-18 & $16200 \pm 310$ & $16040 \pm 310$ & $16220 \pm 310$ \\
\hline & LV17-34 & $15550 \pm 440$ & $15420 \pm 440$ & $15630 \pm 450$ \\
\hline & LV17-35 & $15380 \pm 350$ & $15260 \pm 350$ & $15470 \pm 360$ \\
\hline & LV17-36 & $16750 \pm 440$ & $16560 \pm 440$ & $16770 \pm 440$ \\
\hline & LV17-41 & $15980 \pm 310$ & $15830 \pm 300$ & $16040 \pm 310$ \\
\hline & Mean $\pm \sigma /$ SEM & $16020 \pm 720 / 520$ & $15860 \pm 690 / 510$ & $16070 \pm 700 / 520$ \\
\hline \multirow[t]{7}{*}{ CR2 } & LV17-20 & $13000 \pm 310$ & $13070 \pm 310$ & $13270 \pm 320$ \\
\hline & LV17-21 & $14000 \pm 240$ & $13980 \pm 240$ & $14170 \pm 240$ \\
\hline & LV17-23 & $13660 \pm 260$ & $13670 \pm 260$ & $13880 \pm 260$ \\
\hline & LV17-24 & $13710 \pm 320$ & $13720 \pm 320$ & $13930 \pm 320$ \\
\hline & LV17-25 & $13210 \pm 250$ & $13260 \pm 260$ & $13500 \pm 260$ \\
\hline & LV17-27 & $13060 \pm 250$ & $13120 \pm 250$ & $13370 \pm 250$ \\
\hline & Mean $\pm \sigma /$ SEM & $13440 \pm 570 / 430$ & $13470 \pm 550 / 430$ & $13690 \pm 550 / 440$ \\
\hline \multirow[t]{8}{*}{ CR3 } & LV17-03 & $13500 \pm 260$ & $13530 \pm 260$ & $13760 \pm 260$ \\
\hline & LV17-04 & $13070 \pm 290$ & $13130 \pm 290$ & $13370 \pm 300$ \\
\hline & LV17-05 & $12830 \pm 330$ & $12910 \pm 340$ & $13150 \pm 340$ \\
\hline & LV17-06 & $12780 \pm 250$ & $12870 \pm 260$ & $13090 \pm 260$ \\
\hline & LV17-07 & $13070 \pm 290$ & $13130 \pm 290$ & $13330 \pm 300$ \\
\hline & LV17-08 & $12910 \pm 310$ & $12990 \pm 310$ & $13180 \pm 310$ \\
\hline & LV17-12 & $12880 \pm 240$ & $12970 \pm 240$ & $13160 \pm 250$ \\
\hline & Mean $\pm \sigma /$ SEM & $13010 \pm 460 / 400$ & $13070 \pm 450 / 400$ & $13290 \pm 460 / 410$ \\
\hline
\end{tabular}




\begin{tabular}{|c|c|c|c|c|}
\hline \multirow[t]{4}{*}{ CR4 } & LV17-29 & $12800 \pm 260$ & $12890 \pm 270$ & $13110 \pm 270$ \\
\hline & LV17-30* & $10480 \pm 240$ & $10720 \pm 250$ & $11010 \pm 250$ \\
\hline & LV17-37 & $13330 \pm 270$ & $13360 \pm 270$ & $13590 \pm 270$ \\
\hline & Mean $\pm \sigma /$ SEM & $13060 \pm 540 / 470$ & $13130 \pm 520 / 460$ & $13350 \pm 520 / 470$ \\
\hline \multirow[t]{3}{*}{ CR 5} & LV17-38 & $12340 \pm 240$ & $12460 \pm 240$ & $12700 \pm 240$ \\
\hline & LV17-39 & $12420 \pm 230$ & $12540 \pm 250$ & $12770 \pm 240$ \\
\hline & Mean $\pm \sigma /$ SEM & $12380 \pm 380 / 370$ & $12500 \pm 380 / 380$ & $12730 \pm 390 / 380$ \\
\hline Perched boulder & LV17-42 & $16420 \pm 430$ & $16250 \pm 420$ & $16470 \pm 430$ \\
\hline
\end{tabular}

Figures 


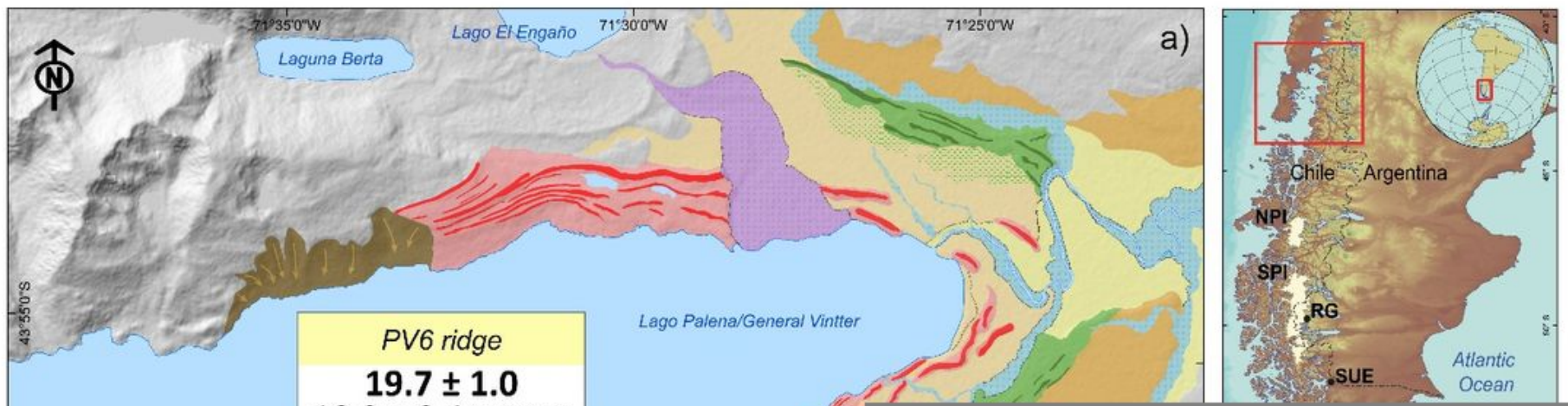

\section{Figure 1}

Glacial geomorphology and chronology of the a) Lago Palena/General Vintter ice lobe with ${ }^{10} \mathrm{Be}$ ages ( $\mathrm{n}$ $=4$ ) obtained from the innermost moraine ridge (PV6) and b) the Cerro Riñón vallley glacier with ${ }^{10} \mathrm{Be}$ ages $(n=26)$ obtained from CR1-CR5 moraine complexes and the additional perched boulder. On top of the boxes the mean moraine age acompanied by 1 standard error of the mean including a $3 \%$ propagated production rate error (Table 1). Individual ages are presented along with internal uncertainty and sample 
ID. One age in red italics is considered an outlier. Inset maps with the location of sites mentioned in the text. Black dots correspond with glacial chronologies from RG: Río Guanaco; SUE: Seno Última Esperanza. Red dots correspond to paleovegetation reconstruction. LL: Lago Lepué. CP: Canal de la Puntilla. TH: Turbera Huelmo. Green dot is the location of ODP1233. White outlines represent Northern (NPI) and Southern (SPI) Patagonian Icefields and Cordillera Darwin Icefield (CDI).

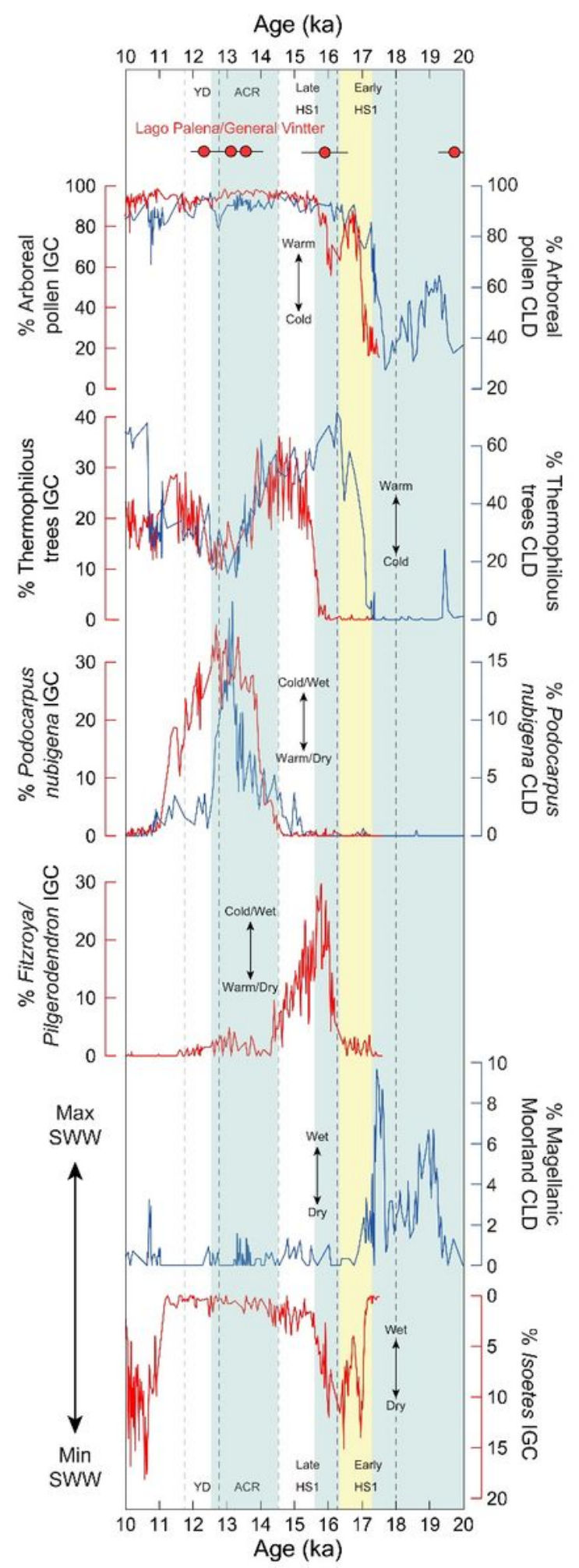

Figure 2 
Glacier chronology of the Lago Palena/General Vintter basin and selected species from the Canal de la Puntilla and Turbera Huelmo in the Chilean Lake District [12] and Lago Lepué pollen record in Isla Grande de Chiloé [36]. Blue bars highlight cold/wet interval and yellow bars demote warm/dry periods within T1.

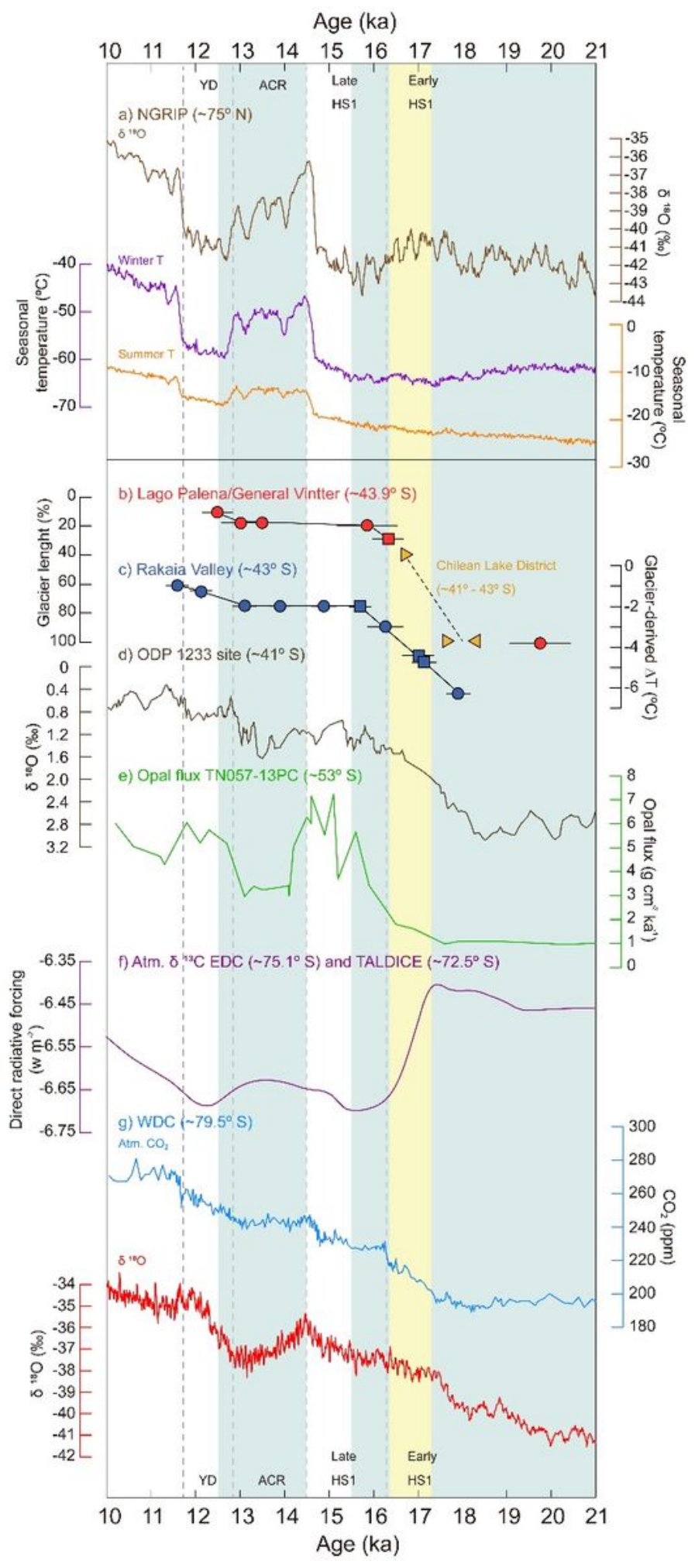

Figure 3 
Paleoclimate proxies spanning T1. a) Records from the North Greenland Ice Core Project: $\delta^{18} \mathrm{O}[3]$; winter temperatures in purple [60]; summer temperatures in yellow [60]. b) Glacier length of the Lago Palena/General Vintter ice lobe (this study). Yellow triangles are bracketing radiocarbon ages for the final glacial advance (100 \% length) of the LGM in the Chilean Lake District [15]. c) Glacier-derived temperatures from Rakaia Valley, New Zealand $[29,30]$. d) Planktonic $\delta^{18} \mathrm{O}$ from marine core ODP-1233 [27]. e) Opal flux from marine core TN057-13PC [9]. f) Integrated $\delta^{13} \mathrm{C}$ from TALDICE and EPICA Dome $\mathrm{C}$ (EDC) [14]. g) Records from the central West Antarctica Ice Core (WAIS): $\mathrm{CO}_{2}$ in light blue and $\delta^{18} \mathrm{O}$ in red. Blue bars highlight cold/wet interval and yellow bars demote warm/dry periods inferred from palinological analyses.

\section{Supplementary Files}

This is a list of supplementary files associated with this preprint. Click to download.

- SoteresetalSupplementary.docx 